\title{
In vitro antitumor efficacy of Kochia indica extract on human hepatocellular carcinoma cell line with or without 5 -fluorouracil
}

\author{
Nabil Mohie Abdel-Hamid', Ghada A. Tabl'2, Yousry E. El-Bolkiny², Walaa O. Zeina ${ }^{2}$ \\ ${ }^{1}$ Department of Biochemistry, Faculty of Pharmacy, Kafrelsheikh University, Kafrelsheikh 33516, Egypt. \\ ${ }^{2}$ Department of Zoology, Faculty of Science, Tanta University, Tanta 71561, Egypt.
}

Correspondence to: Prof. Nabil Mohie Abdel-Hamid, Department of Biochemistry, Faculty of Pharmacy, Kafrelsheikh University, Kafrelsheikh 33516, Egypt. E-mail: nabilmohie@yahoo.com

How to cite this article: Abdel-Hamid NM, Tabl GA, El-Bolkiny YE, Zeina WO. In vitro antitumor efficacy of Kochia indica extract on human hepatocellular carcinoma cell line with or without 5-fluorouracil. Hepatoma Res 2017;3:149-55.

\begin{abstract}
Article history:
Received: 07-12-2016

Accepted: 30-05-2017

Published: 21-07-2017

\section{Key words:}

Hepatocellular carcinoma,

Kochia indica,

5-fluorouracil,

cells of hepatoma cell line,

chemosensitization
\end{abstract}

\begin{abstract}
Aim: Hepatocellular carcinoma (HCC) is the most common primary liver malignancy and the sixth most common cancer worldwide. The resistance to chemotherapy is a major obstacle in the treatment of HCC, necessitating the discovery of additional agents. There is a growing use of anticancer complementary and alternative medicine worldwide. Therefore, the aim of present study was focused on the confirmation of the suitability and validity of the new markers which would be achieved by demonstrating their significant change and reproducible expression during disease and disease management. Methods: $\mathrm{HepG}_{2}$ cell line was used to provide a source for $\mathrm{HCC}$ cells. The cell cultures were divided into 4 groups: control untreated group, 5-fluorouracil (5-FU) treated group as a standard chemotherapy for HCC (positive control) with the following doses $(15.625,31.2,62.5,125,250 \mu \mathrm{g} / \mathrm{mL})$, Kochia indica extract treated group with the following concentration $(12.5,25,50,100,200 \mu \mathrm{g} / \mathrm{mL})$ and the group treated with a combination of 5-FU and Kochia indica in different ratios. Results: Treatment with Kochia indica extract, 5-FU and the combined treatment showed a significant cytotoxicity to $\mathrm{HepG}_{2}$ cells, with different $\mathrm{IC}_{50}$ values, when compared to the control. Regarding toxic effect, 5 -FU showed $\mathrm{IC}_{50}=237.56 \mu \mathrm{g} / \mathrm{mL}$ which is lower cytotoxic in compared to Kochia indica with $\mathrm{IC}_{50}=120.5 \mu \mathrm{g} / \mathrm{mL}$. The results also revealed that tumor cells were more resistant to 5-FU. Alternatively, the co-treatment with Kochia indica extract ameliorated the toxicity induced by $5-\mathrm{FU}$ and enhanced its therapeutic potency, either by synergistic effect of both agents and/or due to its flavonoid components that may enhance the physiological properties of the cell membranes, facilitating 5-FU entrance into tumor cells. This decreased its therapeutic dose to less than $250 \mu \mathrm{g} / \mathrm{mL}$ by combination therapy. Conclusion: Present findings assume that Kochia indica extract co-therapy can ameliorate the side effects of 5-FU on $\mathrm{HepG}_{2}$ by enhancing its cellular uptake.
\end{abstract} cc) (1) (2) This is an open access article distributed under the terms of the Creative Commons Attributionnon-commercially, as long as the author is credited and the new creations are licensed under the identical terms.

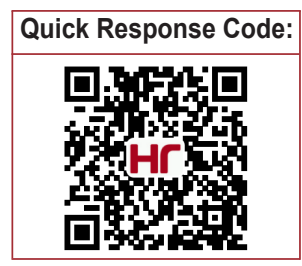




\section{INTRODUCTION}

Hepatocellular carcinoma ( $\mathrm{HCC})$ is the most common primary liver malignancy and the sixth most common cancer worldwide. ${ }^{[1]}$ Also, It is an aggressive malignancy with a poor prognosis and is currently the second most common cause of cancer-related mortality. ${ }^{[2]}$ It was found that about $80 \%$ of the estimated new cases of HCC occurred in less developed regions and its incidence is increasing worldwide in more developed countries $^{[3]}$ including Egypt because of predominant diseases such as hepatitis $\mathrm{C}$ virus $(\mathrm{HCV})$ and schistosomiasis. ${ }^{[4]}$

It was recognized that the resistance to chemotherapy, 5 -fluorouracil (5-FU), is a major obstacle in the treatment of HCC, necessitating the discovery of additional agents. ${ }^{[5]}$ Thus, the use of natural products in this respect is extensively under investigation. ${ }^{[6]}$ One of these products is Kochia indica, family chenopodiaceae [Figure 1]. It was originally introduced as an ornamental plant in some gardens. In the present time, it has spread and is now presented in both crop and no crop areas. ${ }^{[7]}$

The elementary analysis of Kochia indica extract was previously carried out by Haroun ${ }^{[8]}$ using ultraviolet (UV) spectroscopy and infrared spectroscopy, gas chromatography and mass spectrophotometery. As shown in Figure 2, the chemical analysis of Kochia indica extract detects an active phenolic compound

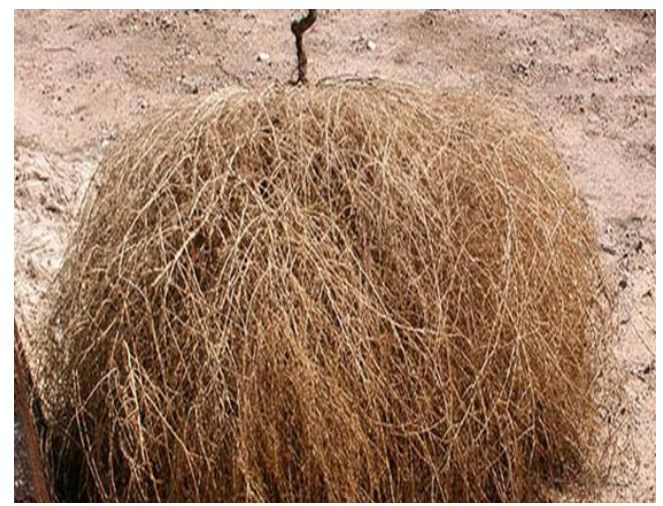

Figure 1: A photograph showing Kochia indica whole plant

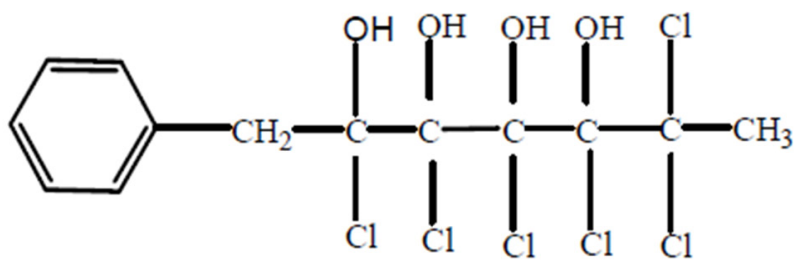

1-phenyl 2,3,4,5,6,6 hexa chloro 2,3,4,5 tetra hydroxy heptan

Figure 2: Phenolic active compound of Kochia indica plant extract ${ }^{[8]}$ with proposed molecular formula $\mathrm{C}_{13} \mathrm{H}_{14} \mathrm{Cl}_{6} \mathrm{O}_{4}$, molecular weight 447 and chemical structure, 1-phenyl 2,3,4,5,6 hexachloro 2,3,4,5 tetra hydroxy heptane.

Previous investigators showed that Kochia indica has a great medicinal potency. It is used as a heart tonic agent ${ }^{[9]}$ and it has a strong tumoricidal properties. ${ }^{[8]}$ Additionally, resinous alkaloid, isolated from alcoholic extract of the plant showed nicotinic action on autonomic ganglia and neuromuscular junctions of voluntary muscles. Fruits and leaves of a related species, Kochiascoparia is used as cardiac tonic, antidermatitis and diuretic agent. ${ }^{[10]}$

Also, ether extract of aerial parts of Kochia contains n-alkanes, free alcohols and amixture of sterols, mainly sitosterol (70.9\%). Ether plant extract exhibited antibacterial activity which is attributed to hydrocarbons and sterols present in its parts.

As known, one of the excellent chemotherapeutic drugs is 5-FU. Despite the excellent therapeutic effects of 5-FU, its cytotoxicity and genotoxicity in normal cells remain a major health problem. ${ }^{[11]}$ Therefore, thinking about herbal use is gradually growing worldwide to reduce the hepatotoxicity induced by $5-\mathrm{FU}$ treatment. The present work was undertaken to test whether Kochia indica extract can exhibit antitumor effect by itself and can improve the antitumor efficacy of 5-FU treatment by reducing its probable side effects.

\section{METHODS}

\section{Chemicals, cultures and reagents}

The anti-cancer 5-FU obtained as an ampoule $(10 \mathrm{~mL})$ contains $250 \mathrm{mg}$ of fluorouracil was stored below $30{ }^{\circ} \mathrm{C}$, protected from light and preserved in sealed containers. It is manufactured by ACDIMA International (AiT, S.X. Haipu Pharmaceutical Co., Ltd.).

To prepare the standard anticancer treatment regimen of 5-FU, it was diluted with Dulbecco's modified Eagle medium (DMEM) to desired concentrations ranging from 10 to $250 \mu \mathrm{g} / \mathrm{mL}$. The final concentration of dimethyl sulfoxide (DMSO) in each cell culture did not exceed $1 \% \mathrm{v} / \mathrm{v}$, to keep the cytotoxicity of DMSO at less than $10 \%$. However, fluorouracil $(25 \mathrm{mg} / \mathrm{mL})$ stock solution was 100 fold diluted $(10 \mathrm{~mL}+990 \mathrm{~mL}$ medium) then it was mixed with the Kochia indica extract in various ratios, and each combination ratio was 2 fold serially diluted. The concentration of each agent in the combination was determined according to the following equation: 
N.V [half maximal inhibitory concentration $\left(\mathrm{IC}_{50}\right)$ for agent separately $]=\mathrm{N}^{-} \cdot \mathrm{V}^{-}$(in combination)

$\mathrm{N}=\mathrm{IC}_{50}$ for the agent, $\mathrm{V}=$ volume of the agent separately $=1$

$\mathrm{N}^{-}=$the concentration of the agent in the combination, $\mathrm{V}^{-}=$the volume of the agent in the combination

Cell culture media, including DMEM and fetal bovine serum (FBS) were purchased from $\mathrm{GIBCO}^{\circledR}$ (Invitrogen). Penicillin and streptomycin, the culture antibiotics, were purchased from (Aldrich-Sigma Company, CA, USA). DMSO, fluorescence dye, Sodium bicarbonate $\left(\mathrm{NaHCO}_{3}\right)$, neutral red, 4-(4'-nitrobenzyl) pyridine (NBP) and 5-FU were also purchased from Sigma-Aldrich. All chemicals and reagents used in the experiments are of highly purified grades.

\section{Hepatoma cell line}

Hepatoma cell line $\left(\mathrm{HepG}_{2}\right)$ was obtained from Holding Company for Biological and Vaccine Production, Cairo, Egypt. $\mathrm{HepG}_{2}$ was maintained in the cell culture laboratory, Medical Research Institute, Smouha, Alex, Egypt. $\mathrm{HepG}_{2}$ is a perpetual cell line consisting of human liver carcinoma cells, derived from the liver tissue of a 15-year-old Caucasian male patient who had a well-differentiated HCC.

\section{Natural agents}

Kochia indica leaf plant was collected nearby Tanta city, Al-Gharbiya Governorate, Egypt. The plant was authenticated visually in taxonomy laboratory at Botany Department, Faculty of Science, Tanta University, Egypt. The collected plants were washed under running tap water and blotted where they were cut into small pieces and kept for drying in oven at temperature $40 \pm 2{ }^{\circ} \mathrm{C}$ for 5 days. The dried plant material was ground into powder and stored in air tight container as described by Prayong et al. ${ }^{[12]}$ The crude ethanolic extracts were dissolved in DMSO at $20 \mathrm{mg} / \mathrm{mL}$ as stock solutions which were then diluted with DMEM to desired working concentrations ranging from 10 to $250 \mu \mathrm{g} / \mathrm{mL}$. The final concentration of DMSO in each sample did not exceed $1 \% \mathrm{v} / \mathrm{v}$, to keep the cytotoxicity of DMSO at less than $10 \%$.

\section{Preparation of $\mathrm{HepG}_{2}$ culture media}

The $\mathrm{HepG}_{2}$ culture media was prepared according to Van der Bliek et al. ${ }^{[13]}$ Briefly, the vial containing $\mathrm{HepG}_{2}$ was placed in a $37^{\circ} \mathrm{C}$ water bath until the contents were thawed and decontaminated immediately by dipping in or spraying with $70 \%$ ethanol. The vial contents were transferred to a centrifuge tube containing $9.0 \mathrm{~mL}$ of absolute DMEM. To prepare DMEM growth medium, FBS was added to reach $10 \%$ final concentration. Prepared cell culture media were spin at approximately
$125 \mathrm{~g}$ for 5-7 min. The cell pellet was suspended again in the medium and dispense into a $25 \mathrm{~cm}^{2}$ culture flask. The culture was incubated at $37^{\circ} \mathrm{C}$ in a $5 \% \mathrm{CO}_{2}$ incubator and thereafter, was ready for sub culturing into working groups.

\section{Experimental cell groups}

HepG ${ }_{2}$ cells were divided into 4 groups described as follow: (1) first group contained $\mathrm{HepG}_{2}$ cells cultured in a media and left without any treatments to serve as a negative control; (2) second group contained $\mathrm{HepG}_{2}$ cells cultured in a media treated with the following doses $(15.625,31.2,62.5,125,250 \mu \mathrm{g} / \mathrm{mL})$ of $5-\mathrm{FU}$ as a standard chemotherapy for $\mathrm{HCC}$ and left to serve as a positive control; (3) third group contained $\mathrm{HepG}_{2}$ cells cultured in a media and treated with the following doses $(12.5,25,50,100,200 \mu \mathrm{g} / \mathrm{mL})$ concentrations of Kochia indica ethanol extract alone and left as an experimental group; (4) fourth group contained $\mathrm{HepG}_{2}$ cells cultured in a media treated with a combination of $5-\mathrm{FU}$ and Kochia indica extract in different ratios (1:1, $2: 1,1: 2,1: 9)$ and left as an experimental group.

\section{Cell viability determination}

The $\mathrm{HepG}_{2}$ culture was sub-cultured at $37{ }^{\circ} \mathrm{C}$ under a humidified environment containing $5 \%$ $\mathrm{CO}_{2}$ incubator. Cytotoxic effect of the tested agents on tumor cells was tested by the neutral red (NR) method described by Fotakis and Timbrell. ${ }^{[14]}$ In brief, tumor cells were seeded in 96-well plates $(100 \mu \mathrm{L} /$ well at a density of $3 \times 10^{5} \mathrm{cells} / \mathrm{mL}$ ) and treated with various concentrations of the used agents for $24 \mathrm{~h}$. Then, cells were washed twice with $1 \times$ phosphate buffer saline and the supernatant was discarded. A total of $100 \mu \mathrm{L}$ of $\mathrm{NR}$ solutions $(50 \mu \mathrm{g} / \mathrm{mL})$ was added to each well and incubated at $37^{\circ} \mathrm{C}$ for another hour. The NR dye was then dissolved in $100 \mu \mathrm{L}$ of $0.33 \% \mathrm{HCl}$. Absorbance of NR dye was detected by a dual-wavelength UV spectrometer (Anthos 2010; Biochrom, UK) at $450 \mathrm{~nm}$ wavelenth. The cytotoxicity was determined against untreated cells by the following equation of Machana et al.:[15] cytotoxicity $(\%)=[100 \times$ (absorbance of untreated group - absorbance of treated group)]/absorbance of untreated group. Therefore, the cell viability $(\%)=100$ - cytotoxicity.

To calculate the $\mathrm{IC}_{50}$ values of the agents under investigation, cytotoxicity (\%) was plotted against agent's working concentrations ${ }^{[14]}$ to give linear equation from which $\mathrm{IC}_{50}$ was calculated. Also, the quantitative efficacy of the combination exposure between 5-FU and Kochia indica extract was determined as a combination index $(\mathrm{Cl})$ according to the following equation: ${ }^{[16]} \mathrm{Cl}=(5-\mathrm{FU})$ in combination/(5-FU) alone + 


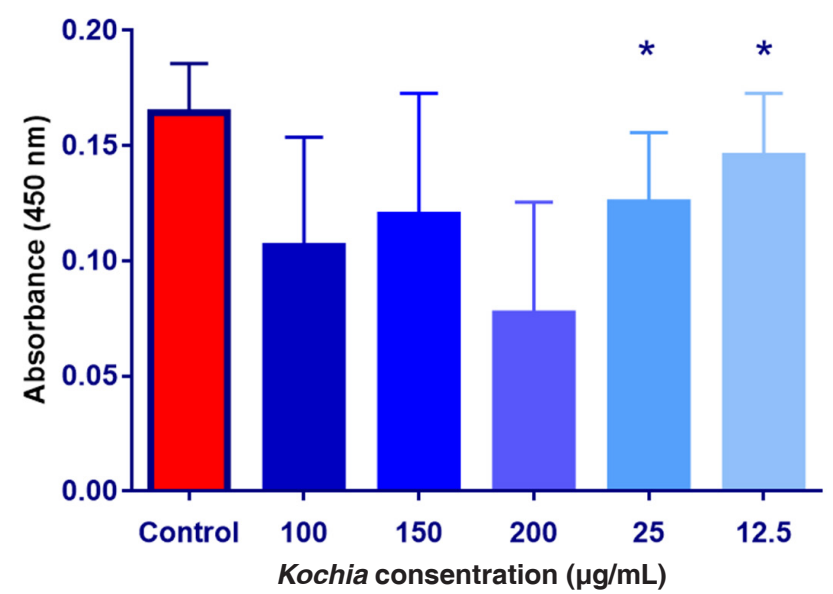

Figure 3: The absorbance values of $\mathrm{HepG}_{2}$ cultured cells exposed to upgrading concentrations of Kochia indica extract. Data are expressed as means $\pm \mathrm{SD}(n=9) ;{ }^{*} P \leq 0.05$ vs. non-treated control group

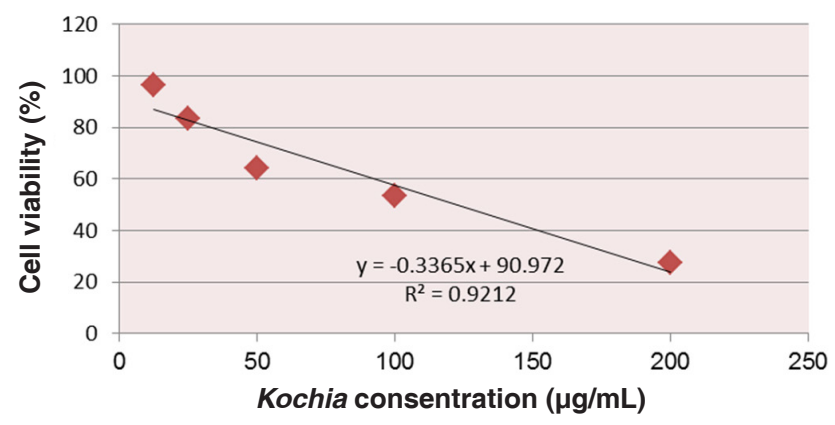

Figure 4: A linear relationship between calculated cell viability of $\mathrm{HepG}_{2}$ cultured cells and concentrations of Kochia indica extract. This linear relationship resulted in $y=-0.3365 x+90.972$ and $R^{2}=$ 0.9212 , from which value of $I_{50}$ was obtained as $121.75 \mu \mathrm{g} / \mathrm{mL}$

( $K$. indica) in combination/ $K$. indica) alone. If $\mathrm{Cl}<1$, it means antagonistic effect; $\mathrm{Cl}=1$, it means synergistic effect; and if $\mathrm{Cl}>1$, it means additive effect.

\section{Statistical analysis}

Data were expressed as means \pm standard deviation ( $n$ $\geq 3$ ). Data of treated groups were statistically analyzed vs. control group by one way analysis of variance (ANOVA), followed by $t$-test using Graph Pad prism 6 Software, CA, USA. However, statistical difference was considered significant if $P \leq 0.05$ confidence interval.

\section{RESULTS}

\section{Effect of Kochia indica extract on $\mathrm{HepG}_{2}$}

As shown on Figure 3, the mean values of absorbance were decreased after the exposure of $\mathrm{HepG}_{2}$ cells to upgrading concentrations of Kochia indica extract compared to the control group. The obtained data were analyzed with ANOVA and showed that the difference among the absorbance values in the control group
Table 1: Effect of upgrading concentrations of Kochia indica extract on the $\mathrm{HepG}_{2}$ cultured cells toxicity and viability $(n=9)$

\begin{tabular}{lcccc}
\hline $\begin{array}{l}\text { Kochia indica } \\
\text { concentration }\end{array}$ & $\begin{array}{c}\text { Cytotoxicity } \\
(\%)\end{array}$ & $\begin{array}{c}\text { Cell viability } \\
(\%)\end{array}$ & $\boldsymbol{t}$ value & $\boldsymbol{P}$ value \\
\hline Control & 0 & 100 & & \\
$12.5 \mu \mathrm{g} / \mathrm{mL}$ & 3.80435 & 96.19565 & 3.761 & 0.0031 \\
$25 \mu \mathrm{g} / \mathrm{mL}$ & 16.48551 & 83.51449 & 1.771 & 0.104 \\
$50 \mu \mathrm{g} / \mathrm{mL}$ & 36.05072 & 63.94928 & 2.555 & 0.028 \\
$100 \mu \mathrm{g} / \mathrm{mL}$ & 46.73913 & 53.26087 & 2.503 & 0.092 \\
$200 \mu \mathrm{g} / \mathrm{mL}$ & 72.46377 & 27.53623 & 1.317 & 0.215 \\
$P$ value & 0.0071 & & & \\
$F$ value & 3.765 & & & \\
\hline
\end{tabular}

and the other groups treated with Kochia indica was significant at $P \leq 0.05$. By application of $t$-test, the difference between means was significant after the exposure of $\mathrm{HepG}_{2}$ cells to 12.5 and $25 \mu \mathrm{g} / \mathrm{mL}$ of the plant extract while the differences between means of other groups were not significant.

Data in Table 1 show the values of both cell toxicity and viability percentages after the exposure of $\mathrm{HepG}_{2}$ cultured cells to all treatments. It was found that the cytotoxicity (\%) was increased with increasing concentration of Kochia indica extract $(12.5-200 \mu \mathrm{g} / \mathrm{mL})$. Oppositely, the cell viability (\%) of $\mathrm{HepG}_{2}$ was gradually decreased with increasing concentration of the plant extract. Therefore, as the concentration of Kochia indica extract increases, the cytotoxicity (\%) of $\mathrm{HepG}_{2}$ increases, and vice versa for the \% of the cell viability which decreases with the increase of the extract concentration [Figure 4].

\section{Effect of 5-FU concentrations on HepG}

As shown on Figure 5, the absorbance values were decreased after the exposure of $\mathrm{HepG}_{2}$ cultured cells exposed to various concentrations of 5-FU compared to the control group. ANOVA showed that the difference among the absorbance values in the control group and the other groups treated with 5-FU was significant at $P$ $\leq 0.05$. To determine the significance, $t$-test was applied on the obtained data and showed that the difference between means was significant after the exposure of $\mathrm{HepG}_{2}$ cells to 125 and $250 \mu \mathrm{g} / \mathrm{mL}$ of $5-\mathrm{FU}$, but not significant with other groups.

Results in Table 2 demonstrates that the percentage of cytotoxicity increased gradually by increasing the concentration of 5-FU, while the viability (\%) of $\mathrm{HepG}_{2}$ cultured cells was decreased. The absorbance means of two groups exposed to both concentrations 125 and $250 \mu \mathrm{g} / \mathrm{mL}$ of 5 -FU were significantly different $(P \leq$ $0.05)$ compared to the control.

Data depicted in Figure 6 show the relationship 


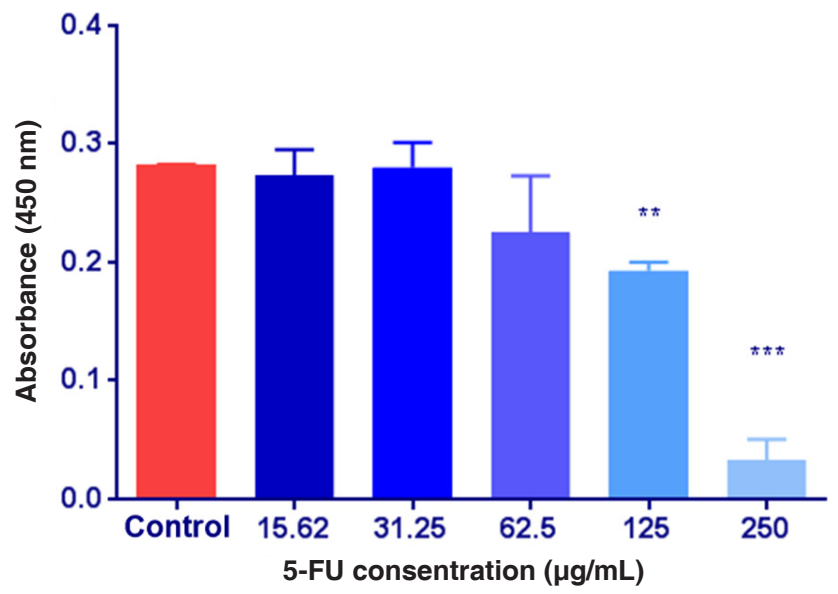

Figure 5: The absorbance values of $\mathrm{HepG}_{2}$ cultured cells exposed to 5-fluorouracil (5-FU) various concentrations. Data are expressed as means $\pm \operatorname{SD}\left(n=9,{ }^{* \star} P \leq 0.01,{ }^{* \star *} P \leq 0.001\right.$, vs. non-treated control group

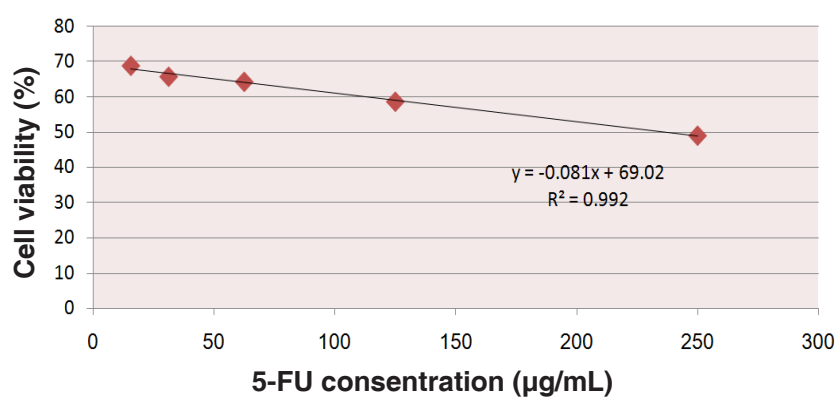

Figure 6: The linear indirectrelationship between cell viability percent of $\mathrm{HepG}_{2}$ cultured cells against upgrading concentrations of 5 -fluorouracil (5-FU), value of $\mathrm{IC}_{50}$ that gives $50 \%$ viability was obtained as $234.342 \mu \mathrm{g} / \mathrm{mL}$

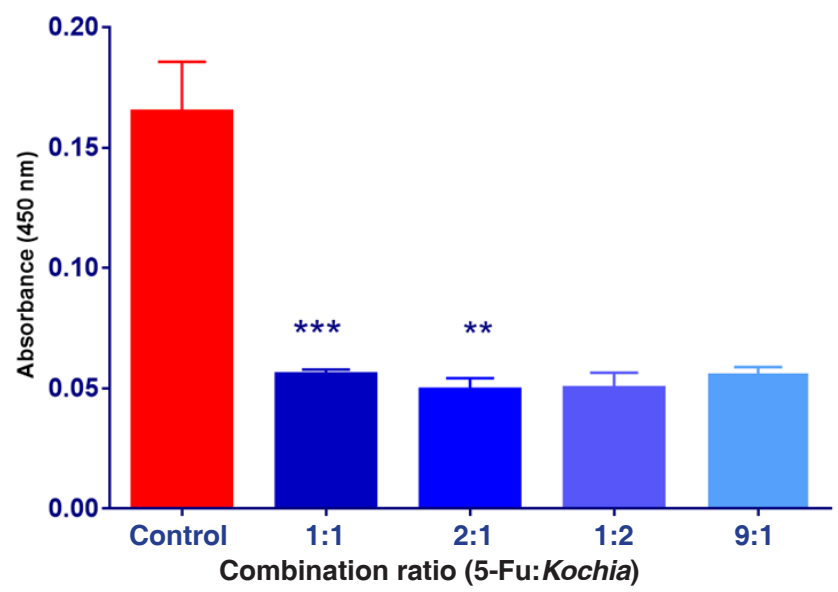

Figure 7: The absorbance values of $\mathrm{HepG}_{2}$ cultured cells exposed to combination ratios of 5-fluorouracil (5-FU) and Kochia indica extract various concentrations. Data are expressed as means $\pm S D$ $(n=9),{ }^{* *} P \leq 0.01,{ }^{\star * *} P \leq 0.001$, vs. non-treated control group

between the percentages of the $\mathrm{HepG}_{2}$ cell viability and upgrading concentrations of $5-\mathrm{FU}$. This relationship gives rise to a linear equation: $y=(-0.081 x+69.02)$ $\left(R^{2}=0.992\right)$ from which $I C_{50}$ be calculated as
Table 2: Effect of upgrading concentrations of $5-\mathrm{FU}$ on the $\mathrm{HepG}_{2}$ cultured cell toxicity and viability $(n=9)$

\begin{tabular}{lcccl}
\hline $\begin{array}{l}\text { 5-FU } \\
\text { concentrations }\end{array}$ & $\begin{array}{c}\text { Cytotoxicity Cell viability } \\
(\%)\end{array}$ & $\begin{array}{c}\boldsymbol{P} \text { value } \\
\text { ( } \boldsymbol{t} \text {-test) }\end{array}$ & $\begin{array}{c}\boldsymbol{t} \text { value } \\
\text { (t-test) }\end{array}$ \\
\hline Control & 0 & 100 & & \\
$15.625 \mu \mathrm{g} / \mathrm{mL}$ & 31.34058 & 68.65942 & $<0.626$ & 0.569 \\
$31.25 \mu \mathrm{g} / \mathrm{mL}$ & 34.42029 & 65.57971 & $<0.891$ & 0.1549 \\
$62.5 \mu \mathrm{g} / \mathrm{mL}$ & 35.86957 & 64.13043 & $<0.2339$ & 0.1686 \\
$125 \mu \mathrm{g} / \mathrm{mL}$ & 41.48551 & 58.51449 & $<0.0031$ & 18.72 \\
$250 \mu \mathrm{g} / \mathrm{mL}$ & 51.08696 & 48.91304 & $<0.0001$ & 17.8 \\
$P$ value (ANOVA) & $<0.0001$ & & & \\
$F$ value (ANOVA) & 78.11 & & & \\
\hline
\end{tabular}

5-FU: 5-fluorouracil; ANOVA: analysis of variance

Table 3: Effect of combination therapy of 5-FU and Kochia indica extract on the $\mathrm{HepG}_{2}$ cultured cells toxicity and viability $(n=9)$

\begin{tabular}{lcccr}
\hline $\begin{array}{l}\text { Combination ratio } \\
\text { 5-FU:Kochia (v:v) }\end{array}$ & $\begin{array}{c}\text { Cytotoxicity } \\
(\%)\end{array}$ & $\begin{array}{c}\text { Viability } \\
(\%)\end{array}$ & $\begin{array}{l}\boldsymbol{P} \text { value } \\
(\boldsymbol{t} \text {-test) }\end{array}$ & $\begin{array}{r}\boldsymbol{t} \text { value } \\
(\boldsymbol{t} \text {-test) }\end{array}$ \\
\hline Control & 0 & 100 & & \\
A ratio of $1: 1$ & 42 & 58 & $<0.0005$ & 1.587 \\
A ratio of $2: 1$ & 53.2 & 46.8 & $<0.0018$ & 2.321 \\
A ratio of $1: 2$ & 52 & 48 & $<0.9319$ & 18.647 \\
A ratio of $9: 1$ & 57 & 43 & $<0.736$ & 15.265 \\
$P$ value (ANOVA) & $<0.0001$ & & & \\
$F$ value (ANOVA) & 67.08 & & & \\
\hline
\end{tabular}

5-FU: 5-fluorouracil; ANOVA: analysis of variance

$234.342 \mu \mathrm{g} / \mathrm{mL}$ of $5-\mathrm{FU}$.

\section{Combination effect of 5-FU and Kochia indica extract on $\mathrm{HepG}_{2}$ cells}

Data shown on Figure 7 shows means of the absorbance values of $\mathrm{HepG}_{2}$ cells exposed to various combination ratios of 5-FU and Kochia indica extract. It was observed that the obtained absorbance in the experimental groups was reduced compared to the control group. Statistical analysis revealed that means of treatments in ratio of 2:1 was more significant than $1: 1$, compared to the control.

Results in Table 3 show the combined effect of both $5-\mathrm{FU}(250 \mu \mathrm{g} / \mathrm{mL})$ and Kochia indica extract $(100 \mu \mathrm{g} / \mathrm{mL})$ on the cell toxicity and viability of $\mathrm{HepG}_{2}$ cultured cells. After the exposure of $\mathrm{HepG}_{2}$ to the combination therapy, data obtained were determined as mean values of the absorbance. Based on the absorbance, the percentage of cytotoxicity was increased while the percentage of the cell viability was decreased by increasing the combination ratios. The most effective ratio was found to be $(1: 2,5-\mathrm{FU} /$ Kochia) of both agents and this ratio led to cytotoxicity of $52 \%$ and cell viability of $48 \%$ on $\mathrm{HepG}_{2}$ cultured cells.

By the application of $\mathrm{Cl}$ equation on the ratio of $1: 2, \mathrm{Cl}$ can be calculated as: $\mathrm{Cl}=83.33 / 250+66.66 / 100=0.33$ 
$+0.6666=0.9966=1$ in approximately (synergistic effect). Accordingly, when $2 \mathrm{v}$ of Kochia indica extract was added to $1 \mathrm{v}$ of $5-\mathrm{FU}$, there is a synergistic effect on the cell viability of $\mathrm{HepG}_{2}$.

\section{DISCUSSION}

The in vitro cytotoxicity test was mainly performed to screen potentially toxic compounds that affect basic cellular functions. This toxicity is measured with cellular damage using NR which is a weak cationic dye that penetrates and accumulates in the lysosomes of living cells. Therefore, NR assay was used to determine the cell viability or, in other words, the toxicity of the test compounds. ${ }^{[14]}$

Data obtained from in vitro study on Kochia indica extract, 5-FU and combination treatment showed a significant cytotoxic effect to $\mathrm{HepG}_{2}$ cultured cells, with different $I C_{50}$ values, when compared to the control. For example, the value of $\mathrm{IC}_{50}$ of Kochia indica extract was found to be $120.5 \mu \mathrm{g} / \mathrm{mL}$. Also, a previous study showed that Kochia indica seeds exerted lethal effect on tumor cells $\mathrm{IC}_{50}=0.147 \mathrm{mg} / \mathrm{mL}$ which may indicate that the seeds of this plant have serious toxic side effects than other parts. ${ }^{[8]}$

Other studies showed different results between aqueous and alcoholic extracts of Kochia indica where the anticancer activity of the aqueous extract was 2.88 and anticancer activity of the ethanolic extract was 1.6. It was observed that the aqueous extract is more potential than the ethanolic one. ${ }^{[15]}$

Many studies showed that Kochia indica extract is rich in flavonoids ${ }^{[16]}$ and alkaloids. ${ }^{[9]}$ Therefore, it has many biological properties about its mode of action such as antioxidant, ${ }^{[17]}$ heart tonic ${ }^{[9]}$ and anticancer effect. ${ }^{[5,9,17]}$ Many cancers develop resistance to chemotherapy, thus lowering its anticancer efficacy. As current treatments become inadequate, higher doses of anticancer therapies such as 5-FU and other novel therapies are used in treating cancers. Such higher dose therapies can lead to cytotoxic and genotoxic side effects in normal cells. ${ }^{[18]}$

According to the above information, 5-FU is a widely used anticancer drug, but the response to it shows low efficacy, approximately $20 \% .{ }^{[19]}$ Thus, many studies have investigated 5-FU with other anticancer drugs such as antioxidants. ${ }^{[20]}$ However, cytotoxicity is nearly inevitable when a combination of 5-FU and antioxidants is used, which remains a major problem in chemotherapy. ${ }^{[21]}$

In the present study, 5-FU showed $\mathrm{IC}_{50}=237.56 \mu \mathrm{g} / \mathrm{mL}$ which is a lower cytotoxic in comparing with Kochia indica with $\mathrm{IC}_{50}=120.5 \mu \mathrm{g} / \mathrm{mL}$ which emphasize the resistance of $\mathrm{HepG}_{2}$ cells to $5-\mathrm{FU}$ as a chemotherapeutic agent. The current work showed also additive synergistic effect when 5-FU combines with Kochia indica extract by ratio of $2: 1(\mathrm{v} / \mathrm{v})$ in the treatment of $\mathrm{HepG}_{2}$ cultured cells. A previous study showed two dual effects when 5-FU enhanced with antioxidant such as, Bupleuri Radix that enhanced 5-FU induced cytotoxicity in $\mathrm{HepG}_{2}$ hepatoma cells, and protected normal lymphocytes from 5-FU induced cytotoxicity. ${ }^{[22]}$

Results of $\mathrm{IC}_{50}$ obtained above showed that the treatment of $\mathrm{HCC}$ with either 5-FU or Kochia indica extract alone can lead to a cytotoxic effect to the target tumor cells. Instead, the combination between a wellknown chemotherapy such as 5-FU and antioxidant such as Kochia indica extract can ameliorate the toxicity induced by 5 -FU as well as enhance the therapeutic potency of 5-FU toward cancer cells by what is known synergistic effect of both agents. The present results can also suggest that flavonoids found in Kochia indica extract enhance the physiological properties of the cell membranes facilitating 5-FU entrance into tumor cells which were resistant to 5-FU, and hence decrease the therapeutic dose to be less than $250 \mu \mathrm{g} / \mathrm{mL}$ as shown in combination therapy. These results are considered as a first line in studying the possible efficacy of Kochia indica extract as an anti cancer agent or as adjuvant with 5-FU, however, further in vivo studies are suggested at experimental animal sessions.

\section{Authors' contributions}

Study design: N.M. Abdel-Hamid

Experimental work: W.O. Zeina, G.A. Tabl

Manuscript drafting: Y.E. El-Bolkainy

Manuscript revision: N.M. Abdel-Hamid, W.O. Zeina

\section{Financial support and sponsorship}

None.

\section{Conflicts of interest}

There are no conflicts of interest.

\section{Patient consent}

Not applicable.

\section{Ethics approval}

University of Tanta approved the whole work prior to any work.

\section{REFERENCES}

1. Ferlay J, Soerjomataram I, Dikshit R, Eser S, Mathers C, Rebelo 
M, Parkin DM, Forman D, Bray F. Cancer incidence and mortality worldwide: sources, methods and major patterns in GLOBOCAN 2012. Int J Cancer 2015;136:E359-86.

2. Dhanasekaran R, Venkatesh SK, Torbenson MS, Roberts LR. Clinical implications of basic research in hepatocellular carcinoma. $J$ Hepatol 2016;64:736-45

3. Colquhoun SD. Hepatocellular carcinoma: the current role of surgical intervention. Crit Rev Oncog 2016;21:93-103.

4. Shaker MK, Abdella HM, Khalifa MO, El Dorry AK. Epidemiological characteristics of hepatocellular carcinoma in Egypt: a retrospective analysis of 1313 cases. Liver Int 2013;33:1601-6.

5. Mazzio EA, Soliman KF. In vitro screening for the tumoricidal properties of international medicinal herbs. Phytother Res 2009;23:385-98.

6. Abdel-Hamid NM, Nazmy MH, Abdel-Bakey AI. Polyol profile as an early diagnostic and prognostic marker in natural product chemoprevention of hepatocellular carcinoma in diabetic rats. Diabetes Res Clin Pract 2011;92:228-37.

7. El Shereef AA. Kochiaplant as potential forage for ruminants under desert conditions. Annu Res Rev Bio 2016;10:1-6.

8. Haroun SA. Mutageneic effects of Kochiaindica extract on Viciafaba L. J Am Sci 2010;6:292-7.

9. Youssef RSA. Medicinal and non-medicinal uses of some plants found in the middle region of Saudi Arabia. J Med Plant Res 2013;7:250117.

10. Khare CP. Indian Medicinal Plants: An Illustrated Dictionary. New York: Springer; 2007. p. 812.

11. Nasr M, Ghorab MK, Abdelazem A. In vitro and in vivo evaluation of cubosomes containing 5-fluorouracil for liver targeting. Acta Pharm Sin B 2015;5:79-88.

12. Prayong $\mathrm{P}$, Barusrux $\mathrm{S}$, Weerapreeyakul N. Cytotoxic activity screening of some indigenous Thai plants. Fitoterapia 2008;79:598-601.

13. Van der BliekAM, Baas F, Ten Houte de Lange T, Kooiman PM,
Van der Velde-Koerts T, Borst P. The human mdr3 gene encodes a novel p-glycoprotein homologue and gives rise to alternatively spliced mRNAs in liver. EMBO J 1987;6:3325-31.

14. Fotakis G, Timbrell JA. In vitro cytotoxicity assays: comparison of LDH, neutral red, MTT and protein assay in hepatoma cell lines following exposure to cadmium chloride. Toxicol Lett 2006;160:1717.

15. Machana S, Weerapreeyakul N, Barusrux S, Nonpunya A, Sripanidkulchai B, Thitimetharoch T. Cytotoxic and apoptotic effects of six herbal plants against the human hepatocarcinoma (HepG2) cell line. Chin Med 2011;6:39.

16. Chou TC, Talalay P. Quantitative analysis of dose-effect relationships the combined effects of multiple drugs or enzyme inhibitors. $A d v$ Enzyme Regul 1984;22:27-55.

17. AbouZid S. Evaluation of usefulness of wild plants growing in BeniSueif Region, Upper Egypt. Funct Plant Sci Biotechnol 2011;5;91-3.

18. Marelli L, Stigliano R, Triantos C, Senzolo M, Cholongitas E, Davies N, Burroughs AK. Treatment outcomes for hepatocellular carcinoma using chemoembolization in combination with other therapies. Cancer Treat Rev 2006;32:594-606.

19. Abdel-Hamid NM, Nazmy MH, Mahmoud AW, Fawzy MA, Youssof M. A survey on herbal management of hepatocellular carcinoma. World J Hepatol 2011;3:175-83

20. Yoo BK, Gredler R, Vozhilla N, Su ZZ, Chen D, Forcier T, Shah K, Saxena U, Hansen U, Fisher PB, Sarkar D. Identification of genes conferring resistance to 5-fluorouracil. Proc Natl Acad Sci U S A 2009;106:12938-43

21. Aboul-Enein AM, El-Ela FA, Shalaby EA, El-Shemy HA. Traditional medicinal plants research in Egypt: studies of antioxidant and anticancer activities. J Med Plant Res 2012;6:689-703.

22. Holaha NS, El-Azab DS, Aiada HA, Sweedb DM. Hepatocellular carcinoma in Egypt: epidemiological and histopathological properties. Menoufia Med J 2015;28:718-24 